難治性痔瘦を合併した非定型的潰瘍性大腸炎の 1 例

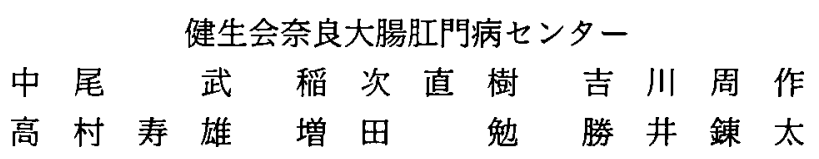

肛門周囲膿湯を契機に重症化した非定型的潰瘍性大腸炎 (以下 UC) の症例を経験した ので文献的考察を加え報告する.症例は 24 歳, 男性. 平成 6 年 (22歳) 発症時より全大 腸炎型の UC と診断され，治療により緩解していた。平成 8 年12月下旬に肛門周囲膿煌 を契機に炎症が再燃した。9 時から 3 時方向にかけて坐骨直腸窩膿瘍を認め, seton 法で 膿湟ドレナージを行った．ステロイド大量投与に反応せず下血が持続した．大量下血を 認めたため, 平成 9 年 1 月 8 日緊急手術 (大腸要全摘, 一時的回腸慺, $\mathrm{S}$ 状結腸粘液瘦造 設術）を行った．切除標本では上行結腸，下行結腸，S 状結腸に区域性に綎走潰貆を認め たが，病変間の粘膜は肉眼上健常にみえた，術後合併症を生じることなく経過したが， 難治性特瘦となった。疛瘦が治癒するまでまち，初回手術より８力月後回腸襄下部直腸 吻合術を行った. 以後疛痶の再発はなく経過良好である.

索引用語：潰瘍性大腸炎, 肛門周囲膿湟, 区域性病変

\section{はじめに}

炎症性腸疾患, 特にCrohn 病 (CD) に肛門病変が合 併することはよく知られている゙が潰場性大腸炎（以 下 UC)の報告例は少ない2(3). 今回われわれは肛門周囲 膿瘍を契機に再燃重症化し，切除標本で区域性に繸走 潰場を認めた非定型的 UCの 1 例を経験したので文献 的考察を加えて報告する.

$$
\text { 症例 }
$$

患者：24歳, 男性.

主訴：肛門痛, 血性下痢.

既往歴：特記事項なし。

家族歴：特記事項なし.

現病歴：平成 6 年 (22歳時) 6 月発症の全大腸炎型 のUCと診断され加療をうけていた。平成 8 年 3 月に 再燃したが内服治療で緩解を維持していた．同年12月 22日より発熱，肛門痛が出現し，25日他院を受診。肛 門周囲膿瘍と診断され切開排膿を受け同日入院。排膿 が持続し，28日より血性下痢が出現したため, 精査加 療目的に12月31日当院に転院となった。

2001年 3 月 8 日受付 2001 年 5 月 8 日採用 〈所属施設住所〉

下635-0022 大和高田市日之出町12-3
入院時現症: 身長 $171 \mathrm{~cm}$, 体重 $57 \mathrm{~kg}$. 体格栄養中等 度. 眼結膜に貧血黄染なし. 血圧 $120 / 70 \mathrm{mmHg}$, 脈拍 92/分整. 体温 $39.1^{\prime \prime C}$. 胸部異常なし. 左下腹部に圧痛 を認めた．直腸肛門診にて粘血便を認め，9時から 3 時方向にかけて IIIA 型肛門周囲膿緜を認め(図 1 ), 肛 門管の12時方向に一次口と会陰部 1 時方向に他院で施 行されたドレナージ切開創を認めた（図 2 ）。

入院時検查所見 : 末梢血白血球 $14700 / \mu \mathrm{l}, \mathrm{CRP} 10.0$ $\mathrm{mg} / \mathrm{d} l$, TP $5.1 \mathrm{~g} / \mathrm{d} l$, Alb 2.6g/d $l$ と白血球, CRP の 著明な上昇と低蛋白血症を認めた。便中細菌培養は陰 性であった。

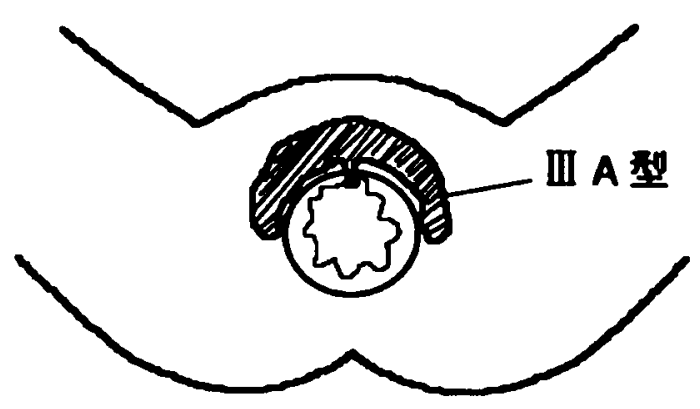

図 1 : 直腸肛門診にて 9 時から 3 時方向にかけて坐骨直 腸窝膿濯を認めた。 


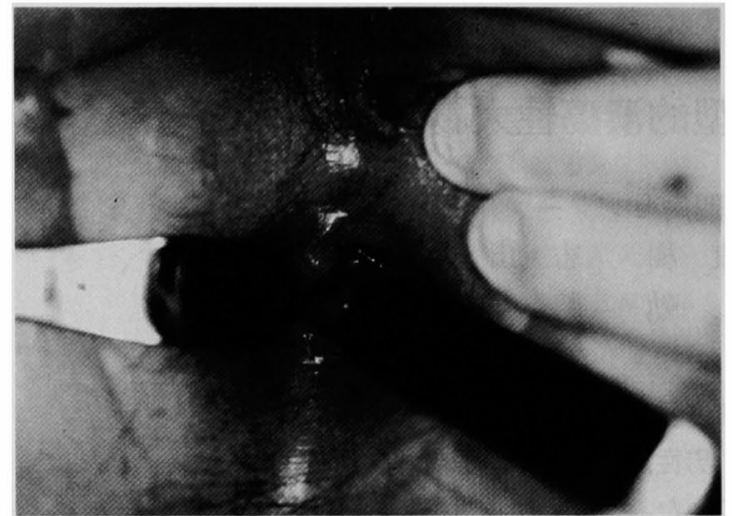

図 2 : 肛門管の 12 時方向に一次口と会陰部 1 時方向にドレ ナージ切開創を認めた。

大腸内視鏡検査所見：直腸は微細顆粒状粘膜を呈し ていたが，炎症は軽微であった。

注腸 $\mathrm{X}$ 線検查所見：入院後翌日に行ったところ, $\mathrm{S}$ 状結腸, 下行結腸, 上行結腸に分節状に深い縦走潰場 を認めた(図 3 )。しかし直腸, 横行結腸には明らかな 潰瘍性病変は認められなかった。

入院後経過: 平成 8 年 12 月 31 日入院. 同日腰椎麻酔 下 seton 法で肛門周囲膿瘍ドレナージ術を行った．排 便回数 $5 \sim 6$ 行/日で下血が持続したため, 1 月 6 日よ りステロイドパルス療法を開始した。しかし大量下血 を認め, $\mathrm{Hb} 7.4 \mathrm{~g} / \mathrm{d} l$ と低下した. 保存的治療の限界と 判断し, 平成 9 年 1 月 8 日緊急手術を行った.

手術所見：正中切開で開腹したところ，ダグラス窩 に少量の漿液性腹水を認めた. $\mathrm{S}$ 状結腸, 下行結腸, 上 行結腸では漿膜面にも発赤を認め, 炎症の波及が考元 られた. 小腸には狭窄, 拡張の所見はなく, 漿膜面の 炎症等も認めなかった。

術中大腸内視鏡検査所見 : $S$ 状結腸, 下行結腸, 上行 結腸に分節状に巨大な深掘れ潰瘍を認めた。潰瘍間に 発赤を伴う浮腫状粘膜の残存を認めた。直腸，横行結 腸の粘膜は軽度の発赤，浮腫を認めた（図 4 ）。

以上より大腸亜全摘, 一時的回腸瘦, S 状結腸粘液瘦 造設術を行った。

切除標本肉眼所見 : $\mathrm{S}$ 状結腸, 下行結腸, 上行結腸 に分節状に深い縦走潰瘍とその間に残存する浮腫状粘 膜を認めた。病変間に介在する粘膜は肉眼上健常のよ うにみえた(図 5 )。上行結腸の拡大像では, 結腸紐に ほほ一致した縦走潰瘍を認めた（図6).

病理組織学的所見：肉眼的健常部の病理組織像で も, 粘膜から粘膜下層まで炎症細胞浸潤が認められた。

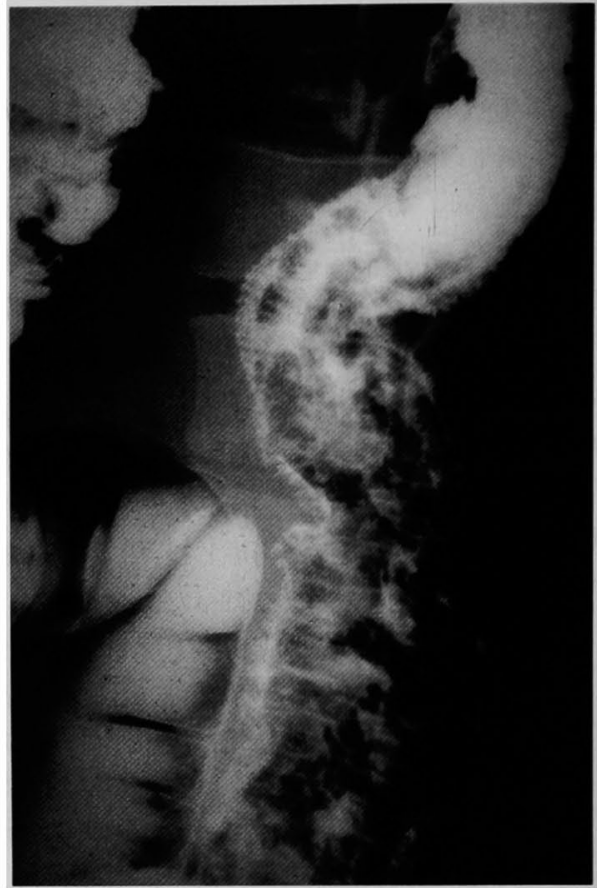

図 3 : 注腸 $X$ 線検査では下行結腸に深い縦走潰 瘍を認めた。

上行結腸の縦走潰瘍部の病理組織像では結腸紐にほほ 一致した UL-II から一部 UL-IIIの潰瘍を認めた(図 7).

術後経過：経過は良好であったが, setonドレーン より排膿が持続した。 1 月29日排膿がみられなくなり ドレーンを抜去した。しかし再び痔瘦の二次口より排 膿がみられ，2 月17日腰椎麻酔下 coring out 法十皮膚 弁移動術（SSG）による一次口閉鎖+ドレナージを施 行した。 3 月 3 日ドレーンを抜去し， 3 月 5 日（術後 56日目）に退院. しかし痔瘦の二次口より排膿がみら れ, 入院し 5 月28日腰椎麻酔下 coring out 法 + SSG + ドレナージを行った.ドレーンを挿入したまま退院し, 7 月19日外来でドレーンを抜去した，痔瘦の治癒傾向 をみて, 初回手術より 8 力月後の平成 9 年 8 月 27 日回 腸囊下部直腸吻合術を行った。9月13日わずかに残存 する低位筋間痔瘦に対してゴム輪によるcutting seton 法でドレナージを行った．特に肛門痛を生じる ことなく 10 月 2 日自然に cuttingされ 10 月 7 日退院し た。肛門括約筋機能もよく保たれていた。結局肛門周 囲膿瘍, 難治性痔瘦に対して 4 回手術を行い, 総ドレ ーン留置期間は cutting setonも含めると118日に及ん だ，以後経過は良好で，現在まで残存直腸の炎症の再 燃, 痔瘦の再発を認めていない. 


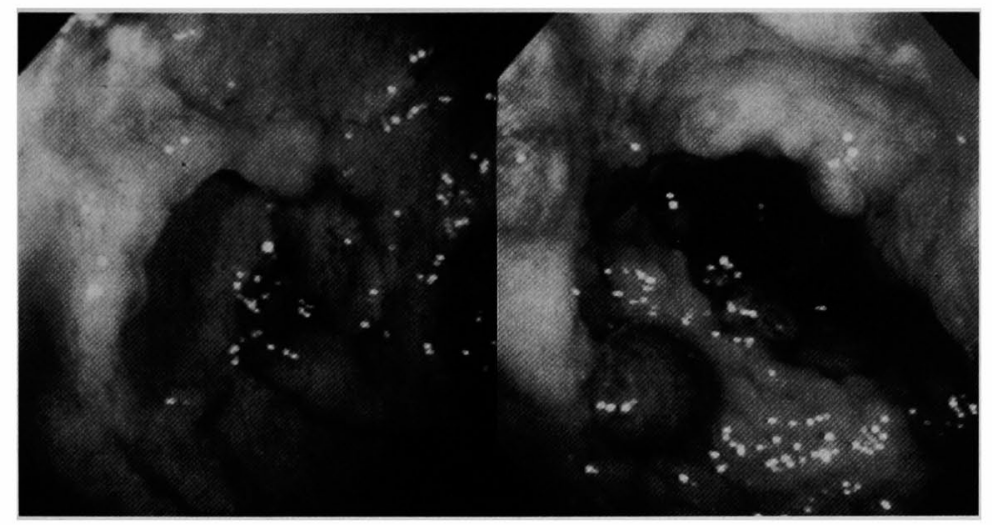

図 4 ：上行結腸 (左)，下行結腸 (右)に分節状に巨大な深掘れ潰瘍を認めた。潰 瘍間に発赤を伴う浮腫状粘膜の残存を認めた.

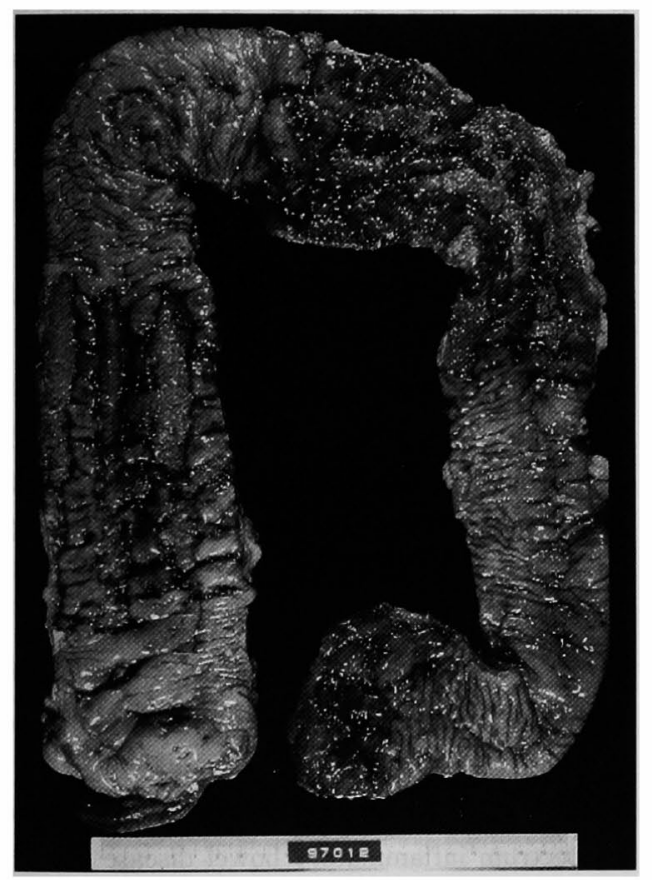

図 5：S 状結腸,下行結腸, 上行結腸に分節状に深い 縦走潰瘍とその間に残存する浮腫状粘膜を認め た. 病変間に介在する粘膜は肉眼上健常のように みえた。

\section{考 察}

肛門周囲膿瘍を契機に重症化した非定型的潰瘍性大 腸炎の症例を経験した。 Seton 法で膿瘍ドレナージを 行ったが難治性痔瘦となり, 完治するまで10力月を要 した．CDに肛門病変が合併することはよく知られて おり診断基準にあげられている11. 肛門病変の合併頻

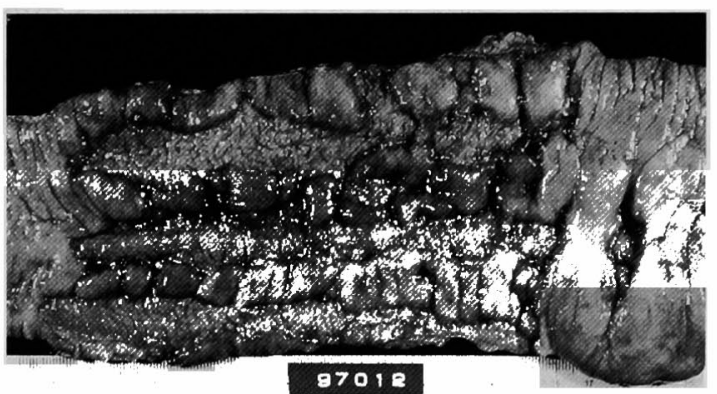

図 6 ：上行結腸の拡大像では，結腸紐にほほ一致した縦走 潰瘍を認めた。

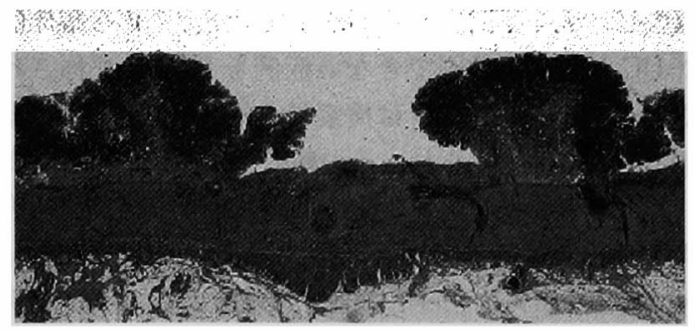

図 7 ：上行結腸の緃走潰瘍部の病理組織像では結腸紐 にほほ一致した UL-IIから一部 UL-IIIの潰瘍を認め た.

度は施設によりさまざまであるが, 当センターで治療 している CD 患者55例を検討したところ，45例 (82\%) が何らかの肛門病変を合併していた ${ }^{21}$.しかしUCの 肛門病変の報告は少ない年4). 当センターで治療してい るUC 患者246例中では痔瘻・肛門周囲膿瘍は自験例も 含め 9 例 $(3.6 \%)$ で, 難治性痔瘻は 2 例でいずれも非 定型的 UCの症例であった。 
切除標本では区域性に縦走潰瘍を認め, 病変間の大 腸粘膜は肉眼的には健常であるように思われた。内視 鏡所見では直腸の炎症は軽微であった.UCの非定型 例として松川ら ${ }^{51}$ は区域性病変を, 大井ら ${ }^{6}$ は綖走潰瘍 をみとめたケースを報告している。渡辺ら”は，UCの 綐走潰場は手術例25例中 8 例（32\%）にみられたとし， 大井ら ${ }^{6}$ は119例中20例（17\%）にみられ，高齢者もし くは䍜患期間の長い症例，また手術例が多かった（21

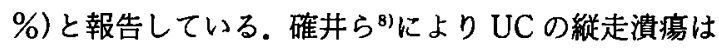

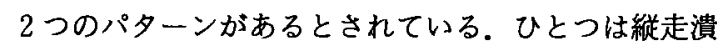
瘍が炎症性ポリポーシスの間に認められるもので結腸 紐との関係は乏しいもの，つまりUC 自体により粘膜 の脱落のために生じたもので，もう一つは炎症性ポリ 一プを認めず，結腸紐と規則性があり，2〜3本認め られるもので, 虚血性腸炎のタイプに類似するもので ある. 自験例ではいずれも綐走潰瘍はほぼ結腸紐に一 致して存在した，組織所見で虚血を示す担鉄細胞は証 明されてはいないが，何らかの虚血性変化の合併が考 えられた。このような症例が初診である場合, 診断に 苦慮することが考えられる. 多田ら很えよると, 内視鏡 的に健常粘膜と思われる部分の生検の病理組織所見で 炎症性変化を認める場合はUC と診断してよいとされ る.

欧米では Price ${ }^{101}$ が切除され病理学的に検索された あとでも UC か CD か診断できない症例を一時的な組 織診断名として indeterminate colitis（以下 IND）と 報告し，広く認識されるようになった。そ後臨床的 にUCと CD を鑑別できない症例も IND と呼称され るようになった. IND は険索が十分出来ない重症, 緊 急手術例に多くみられ, その頻度は $10 \%$ 前後とされて いる. 本邦では厚生省難治性炎症性腸管障害調查研究 班の平成 9 年度の分類不能型大腸炎 (indeterminate type colitis）アンケート調査で12施設より, IND 症例 10例が集計されている"11.UCの吻合術式としては IAA, IACA，IRA があり，CDではIAA は禁忌とさ れる11．UCか CD か診断に苦慮する場合はまず大腸 覀全摘, 一時的回腸瘦, S 状結腸粘液瘦造設術を行い, 切除標本の病理検索, 術後の残存腸管の経過観察によ り，確定診断を行い，吻合法を決定すべきと考える.

\section{結語}

肛門周囲膿瘍を契機に重症化し，難治性庤瘭を合併 した非定型的潰瘍性大腸炎の症例を経験したので報告 した.

\section{文献}

1）八尾恒良：クローン病診断基準(案). 厚生省特定 疾患難治性炎症性腸管障害調查研究班 平成 6 年 度研究報告書 : $63-66,1995$

2) 勝井鍊太, 稲次直樹, 吉川周作他：Crohn 病の肛 門病変の治療について. 日臨外医会誌 60 (増刊 号) : 606, 1999

3）檞口康彦：肛門疾患3193例を母集団とする大腸病 変の拾い上げ。目本大腸肛門病会誌 $43: 197$, 1990

4）関岡敏夫, 仲井 理, 飯塚 修他: 肛門潰瘍を主 症状とした潰瘍性大腸炎の 1 例. 日本大腸肛門病 会誌 $43: 631-635,1990$

5）松川千明, 千葉俊哉, 山崎武志他：潰惶性大腸炎 に打ける非典型的所見 区域性病変. 胃と腸 $33: 1219-1226,1998$

6）大井秀久, 島岡俊治，西俣嘉人他：潰瘍性大腸炎 における非典型的所見 綐走漬瘍. 胃と腸 33： 1227-1242, 1998

7）渡辺英伸，味岡洋一，太田玉紀他：炎症性腸疾㭧 の病理学的鑑別診断. 胃と腸 $25: 659-682,1990$

8）確井芳樹：演瘍性大腸炎にみられる虚血性病変像 に関する診断的研究. 順天堂医 $33: 513-515$, 1987

9）多田正大, 大塚弘友, 北村千都他：非定型的病像 の漬瘍性大腸炎の 1 例. 胃と腸 $30: 1472-1474$, 1995

10) Price AB: Overlap in the spectrum of nonspectrum inflammatory bowel disease "colitis indeterminate". J Clin Pathol $31: 567-577$, 1978

11）馬塲正三: 分類不能型大腸炎 (indeterminate type colitis）アンケート調査. 厚生省特定疾患難 治性炎症性腸管障害調查研究班 平成 9 年度研究 報告書：142-143，1997 


\title{
A CASE OF ATYPICAL ULCERATIVE COLITIS ACCOMPANIED WITH INTRACTABLE ANAL FISTULA
}

\author{
Takeshi NAKAO, Naoki INATSUGI, Syusaku YOSHIKAWA, \\ Hisao TAKAMURA, Tsutomu MASUDA and Renta KATSUI \\ Kenseikai Nara Coloproctology Center
}

We report an atypical case of ulcerative colitis accompanied with intractable anal fistula. A 24year-old man who had been diagnosed as having total colitis type of ulcerative colitis was admitted to the hospital because of perianal abcess and melena when flareups of ulcerative colitis occutred. Incision and seton drainage for the perianal abcess were performed. Pulsed steroid therapy for ulcerative colitis was in effective and massive anal bleeding continued. Emergency operation was perfomed. Operative procedures included subtotal colectomy, ileostomy and mucous fistula of the sigmoid colon. In the surgical speicimen, there were segmental longitudinal ulcers at the ascending, descending and sigmoid colon, but macroscopically normal mucosa between ulcerative lesions. He made an uneventful recovery after the operation, but discharge of anal fistula persisted until 8 months after the operation. Ileal $\mathbf{J}-$ pouch-rectal anastomosis was perfomed, and thereafter intractable anal fistula subsided. No Recurrence of anal fistula has been observed up to now. 